\title{
Switch from Immediate-release Pramipexole to Extended-release Pramipexole: The Safety and Efficacy Characteristics of Sixty-eight Patients
}

\author{
Kısa Etkili Pramipeksolden Uzun Etkili Pramipeksole Geçiş: Altmış Sekiz Hastanın \\ Güvenlik ve Etkinlik Özellikleri
}

\author{
Müge Kuzu1 1 İnci Şule Özer ${ }^{1}$, Oğuzhan Herdi², Sabiha Tezcan ${ }^{1}$, Muhittin Cenk Akbostanc1 ${ }^{1}$ \\ ${ }^{1}$ Ankara University Faculty of Medicine, Department of Neurology, Ankara, Turkey \\ 2Ankara University Faculty of Medicine, Department of Psychiatry, Ankara, Turkey
}

\section{Summary}

Objective: To evaluate the safety and efficacy of switching from immediate-release pramipexole (pex) to extended-release pramipexole (pex-ER).

Materials and Methods: Pex-ER became available in Turkey about a year ago, since then we documented satisfactory information on patients (26 women; $38 \%$ ) who were switched from pex to pex-ER. We recorded pre- and post-switch pex and levodopa, equivalent doses of other anti-parkinsonian medication, and analyzed the frequency and nature of reported adverse effects.

Results: The mean age of the patients was 63.3 years (range, 44-88 years), and the mean disease duration was 7.1 years (range, 1-27 years). The other drugs were levodopa ( 57 patients, $82.6 \%$ ), entacapone (24 patients, 34.58\%), rasagiline (20 patients, 29\%), amantadine (18 patients, 26.1\%), and apomorphine (six patients, $8.7 \%)$. Switch from pex to pex-ER was uneventful in $62(91.2 \%)$ patients. Adverse events were reported in six (8.8\%) patients: ankle swelling (two patients), nausea (one patient), dyskinesia (one patient), hypersexuality (one patient), and psychosis (one patient). Problems resolved with further medication change in two patients. Four patients preferred to return to pex.

Conclusion: The great majority of patients $(91.2 \%)$ switched from three times daily pex to once daily pex-ER uneventfully. A slight increase in pex daily dose, which was tailored according to patients' symptomatic needs, resulted in an increase in post-switch levodopa equivalent doses. Our experience is compatible with previously reported studies.

Keywords: Parkinson disease, dopamine agonist, extended-release pramipexole

\section{$\ddot{\mathbf{O} z}$}

Amaç: Bu çalışmada, kısa etkili pramipeksolden (pex) uzun etkili pramipeksole (pex-ER) geçişteki etkililik ve güvenliğin kendi hasta popülasyonumuz açısından ölçülmesi amaçlanmıştır.

Gereç ve Yöntem: Pex-ER'nin ülkemizde kullanıma girmesinden yaklaşık bir yıl sonra retrospektif olarak Parkinson hastalığı $(\mathrm{PH})$ dosyaları tarandı. Çalışmaya tek gecede pex'den pex-ER'ye geçilen hastalar alındı. Altmış sekiz hasta (26'sı kadın) (\%38) çalışmaya dahil edildi. Hastaların yaş, cinsiyet, hastalık süresi, ek

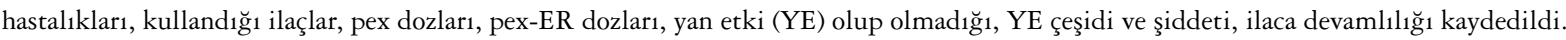

Bulgular: Ortalama yaş 63,3 (44-88 arası), ortalama hastalık süresi 7,1 yıl (1-27 arası) idi. PH için dopamin agonisti dışı kullandıkları ilaçlar levodopa (57 hasta, \%82,6) rasajilin (20 hasta, \%29), amantadin (18 hasta, \%26,1), apomorfin (altı hasta, \%8,7) idi. Hastaların $62(\% 91,2)$ tanesinde pex'den pex-ER geçiş sorunsuz bir şekilde tamamlandı. Altı $(\% 8,8)$ hastada ise YE görüldü. YE'ler; ayak bileğinde şişlik (iki hasta), kusma (bir hasta), diskinezi (bir hasta), hiperseksüalite (bir hasta) ve psikozdu (bir hasta). Pex'den pex-ER'ye geçen hastaların pramipeksol dozu ve levodopa eşdeğer dozu anlamlı derecede artmıştı ( $\mathrm{p}=0,00)$.

\footnotetext{
Address for Correspondence/Yazışma Adresi: Müge Kuzu MD, Ankara University Faculty of Medicine, Department of Neurology, Ankara, Turkey Phone: +905058287112 E-mail: muggykuzu@gmail.com

Received/Geliş Tarihi: 03.12.2015 Accepted/Kabul Tarihi: 11.04.2016

(C) Turkish Journal of Neurology, Published by Galenos Publishing House.

This article is distributed under the terms of the "Creative Commons Attribution NonCommercial 4.0 International Licence (CC BY-NC 4.0)".
} 
Sonuç: Pramipeksol dozu hastaların semptomatik ihtiyaçlarına göre artırılmış olup bu durum pex'den pex-ER'ye geçen hastalarda levodopa eşdeğer dozunun anlamlı derecede artmasına yol açmıştır. Pex'den pex-ER'ye bir gecede geçiş hastaların \%90'ına, sorunsuz gerçekleşmiştir. Bulgularımız önceki çalışmalar ile uyumludur.

Anahtar Kelimeler: Parkinson hastalığı, dopamin agonistleri, uzun etkili pramipeksol

\section{Introduction}

Parkinson's disease (PD) is a chronic, progressive, and degenerative disease associated with rigidity, bradykinesia, resting tremor, postural instability, and freezing. Non-motor symptoms including autonomic dysfunction, depression, anxiety, sleep disorders and cognitive dysfunction can be seen in PD $(1,2)$. PD is the second most common neurodegenerative disease following Alzheimer's disease, and effects $1 \%$ of the population aged over 60 years (3). The prevalence of PD was reported to be 111/100.000 in Eskişehir in a study performed in 1995 and $2.23 \%$ in Bursa in the population aged over 40 years in a study performed in $2009(4,5)$. $\mathrm{PD}$ is associated with selective loss of dopaminergic neurons in the substantia nigra. Dopamine agonists (DA) are used as monotherapy in early PD and add-on treatment in late PD (6).

Pramipexole (pex), a non-ergot DA, differs from other DAs with its high affinity to D3 dopaminergic receptors, which probably makes it effective in the treatment of depression and apathy, and which also likely causes impulse control disorders more often $(7,8,9,10,11)$. End-of-dose worsening and peak-dose dyskinesia are less common in patients with PD when pex is used instead of levodopa as the initial treatment. Also, pex is more effective in the treatment of end-of-dose worsening (12).

The standard formulation of pex is used three times per day, and a new once-daily formulation has been made available in our country recently.

This study aimed to investigate the efficiency and safety of switching from immediate-release pramipexole (pex) to extendedrelease pramipexole (pex-ER) in our patient population.

\section{Materials and Methods}

The medical records of patients with PD were retrospectively analyzed approximately one year after the release of pex-ER in Turkey. The records of 68 patients whose treatments were switched from pex to pex-ER were investigated. Data from participants including age, sex, duration of disease, medical history, drug use, dosages of pex, dosages of pex-ER, adverse effects and their severities, and continuity of treatment were recorded.

Levodopa/carbidopa (CR) + (levodopa/CRx0.75) + tolcapone or entacapone (levodopa/CR + levodopa/CRx0.75)x0.25 + (pex or cabergoline $\mathrm{x} 67)+($ pergolide $\mathrm{x} 100)+($ ropinirole $\mathrm{x} 20)+($ piribedil $\mathrm{x} 50)+($ bromocriptine $\mathrm{x} 10)+($ apomorphine $\mathrm{x} 8$ ) formulations were used to calculate levodopa equivalent doses before and after switching (13). Data were analyzed using SPSS.

\section{Results}

Sixty-eight patients were included in the study, 26 (38\%) of which were women. The mean age was 63.3 years (range, 44-88 years), and the mean duration of disease was 7.1 years (range,
1-27 years). Levodopa was the most commonly used non-DA drug (56 patients, $82.6 \%$ ) followed by rasagiline (20 patients, 29\%), amantadine (18 patients, 26.1\%), apomorphine (six patients, $8.7 \%)$. In $62(91.2 \%)$ patients, the switch from pex to pex-ER was achieved uneventfully. Adverse events including edema of the wrist in two patients, vomiting in one patient, dyskinesia in one patient, hypersexuality in one patient, and psychosis in one patient, were seen in six patients (8.8\%). Problems in two patients were resolved by modifying the treatment, but four patients were switched back to pex from pex-ER. Pex and levodopa equivalent dosages were significantly higher in patients switched from pex to pex-ER, $(\mathrm{p}<0.001)$ (Table 1). The Mann-Whitney U test was used to compare patients with and without adverse events. (Adverse events + , mean $=59.83$, standard deviation=12.85), (adverse events -, mean=63.75, standard deviation=9.09), $(\mathrm{p}=0.33)$. Differences between sexes were compared using Fisher's chi-square and no difference was found $(\mathrm{p}=0.999)$. Severity of disease was not evaluated in this study.

Levodopa equivalent dose was increased in all patients because they were all admitted to hospital while symptomatic.

Table 1. Dosages of pramipexole and levodopa equivalent dosages before and after switch to extended-release pramipexole. Dosages were increased because of patients' symptomatic needs

\begin{tabular}{|llll|} 
& $\begin{array}{l}\text { Dosages before } \\
\text { switch (mg/day) }\end{array}$ & $\begin{array}{l}\text { Dosages after } \\
\text { switch (mg/day) }\end{array}$ & $\mathrm{p}$ \\
Pramipexole & $2.5(\mathrm{SD} 1.3)$ & 3.1 (SD 1.2) & 0.00 \\
$\begin{array}{l}\text { Levodopa- } \\
\text { equivalent Dosage }\end{array}$ & $653.2(\mathrm{SD}$ 498.2) & 719.1 (SD 562.9) & 0.00 \\
SD: Standard deviation & & & \\
\hline
\end{tabular}

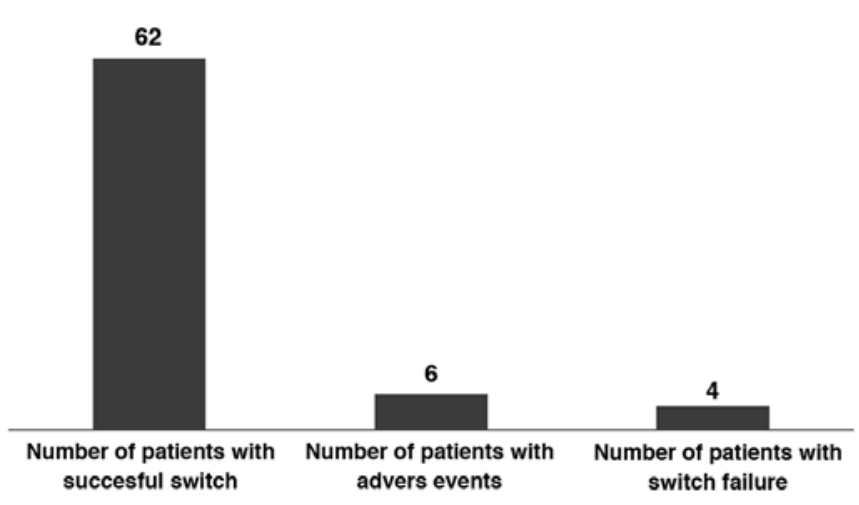

Figure 1. Adverse effects in "switch from pramipexole to extendedrelease pramipexole" group 


\section{Discussion}

This study showed that overnight switch from pex to pex-ER is sufficient and safe. The switch from pex to pex-ER was achieved uneventfully in $92.2 \%$ of patients, adverse events were seen in six of 68 patients, and four patients were switched back to pex from pex-ER (Figure 1). The dosage of pex was increased due to effects of motor symptoms on daily activities of patients. This caused an significant increase in levodopa equivalent dose in patients who were switched from pex to pex-ER.

In a randomized, double-blind, controlled trial by the Pramipexole Working Group, 507 patients with late PD were followed up for 18 weeks and were evaluated using the Unified Parkinson's Disease Rating Scale (UPDRS) scores and "off” times. Pex-ER was found as efficient as pex (level of evidence: Class 1). Changes of UPDRS scores were $-11,-12.8$, and -6.1 , and changes of "off" times were $-2.1,-2.3$, and -1.4 for pex-ER, pex, and the placebo group, respectively (14).

The same working group followed up patients with early PD for 33 weeks and their UPDRS scores were evaluated in the $18^{\text {th }}$ and $33^{\text {rd }}$ weeks. Pex-ER was found as efficient as pex and better than placebo, the changes of UPDRS scores were $-7.4,-7.5$, and -2.7 in the $18^{\text {th }}$ week, and $8.2,-8.3$, and -1.2 in the $33^{\text {rd }}$ week for pex-ER, pex, and placebo, respectively (15).

Another double-blind, randomized, controlled study by the same group included patients who used more than $1.5 \mathrm{mg} / \mathrm{day}$ pex for more than 3 months and 3 times a day. The patients were divided into 2 groups: switch from pex to pex-ER and pseudoswitch from pex to pex-ER. Successful switch was made from pex to pex-ER at the end of 9 weeks in $84.5 \%$ of patients, and this ratio was $94.2 \%$ in the pseudo-switch group. No adverse events were reported that caused switch failure (16). Similarly, switch from pex to pex-ER was made successfully in $92.2 \%$ of patients in our study.

Patients with PD whose disease duration was more than 2 years, with 2-4 Hoehn-Yahr stages and who were aged over 30 years were included in a double-blind, randomized, controlled study in China, which was simultaneously performed in 20 centers. Patients were divided into pex users (IR) $(n=239)$ and pramipexole-ER users (ER) $(n=236)$ and were followed up 18 weeks. When the changes of UPDRS scores were evaluated, pexER was found as efficient and safe as pex, the changes of UPDRS scores were -13.81 and 13.09 for pex-ER and pex, respectively. The incidence of adverse events was $68.8 \%$ in the ER arm and $73.6 \%$ in the IR arm with few severe adverse events (ER: $2.1 \%$; IR: $3.8 \%)$. The most reported adverse events were somnolence, vertigo and nausea (17).

\section{Conclusion}

As a result, considering the dose requirements of patients, switch from pex to pex-ER was found to be safe, which is similar to other study findings.

\section{Ethics}

Ethics Committee Approval: Retrospective study, Informed Consent: Consent form was filled out by all participants.

Peer-review: Externally peer-reviewed.

\section{Authorship Contributions}

Surgical and Medical Practices: Mubittin Cenk Akbostancı, Müge Kuzu, Concept: Mubittin Cenk Akbostancı, Müge Kuzu, Inci Şule Özer, Design: Mubittin Cenk Akbostancı, Müge Kuzu, Inci Şule Özer, Data

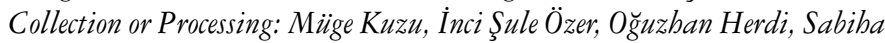
Tezcan, Analysis or Interpretation: Mubittin Cenk Akbostancı, Müge Kuzu, Literature Search: Müge Kuzu, Inci Şule Özer, Writing: Müge Kuzu. Conflict of Interest: No conflict of interest was declared by the authors.

Financial Disclosure: The authors declared that this study has received no financial support.

\section{References}

1. Lohle M, Ramberg CJ, Reichmann H, Schapira AH. Early versus delayed initiation of pharmacotherapy in Parkinson's disease. Drugs 2014;74:645-657.

2. Chaudhuri KR, Healy DG, Schapira AH, National Institute for Clinical E. Non-motor symptoms of Parkinson's disease: diagnosis and management. Lancet Neurol 2006;5:235-245.

3. Sprenger F, Poewe W. Management of motor and non-motor symptoms in Parkinson's disease. CNS Drugs 2013;27:259-272.

4. Torun Ş, Uysal M, Gücüyener D, Özdemir G. Parkinson's disease in Eskişehir, Turkey. Eur J Neurol 1995;2:44-45.

5. Erer Özbek S, Zarifoğlu M, Karlı N, Özçakır A, Yıldız D, Aslan D. A Population-Based Survey to Determine the Prevalence of Movement Disorders in Orhangazi District of Bursa, Turkey. Turk J Neurol 2009;15:109-118.

6. Stowe RL, Ives NJ, Clarke C, van Hilten J, Ferreira J, Hawker RJ, Shah L, Wheatley K, Gray R. Dopamine agonist therapy in early Parkinson's disease. Cochrane Database Syst Rev 2008;CD006564.

7. Perachon S, Schwartz JC, Sokoloff P. Functional potencies of new antiparkinsonian drugs at recombinant human dopamine D1, D2 and D3 receptors. Eur J Pharmacol 1999;366:293-300.

8. Piercey MF. Pharmacology of pramipexole, a dopamine D3-preferring agonist useful in treating Parkinson's disease. Clin Neuropharmacol 1998;21:141-151.

9. Friedman JH. Parkinson's disease psychosis 2010: a review article. Parkinsonism Relat Disord 2010;16:553-560.

10. Breuer ME, Groenink L, Oosting RS, Buerger E, Korte M, Ferger B, Olivier B. Antidepressant effects of pramipexole, a dopamine D3/D2 receptor agonist, and 7-OH-DPAT, a dopamine D3 receptor agonist, in olfactory bulbectomized rats. Eur J Pharmacol 2009;616:134-140.

11. Garcia-Ruiz PJ, Martinez Castrillo JC, Alonso-Canovas A, Herranz Barcenas A, Vela L, Sanchez Alonso P, Mata M, Olmedilla Gonzalez N, Mahillo Fernandez I. Impulse control disorder in patients with Parkinson's disease under dopamine agonist therapy: a multicentre study. J Neurol Neurosurg Psychiatry 2014;85:840-844.

12. A randomized controlled trial comparing pramipexole with levodopa in early Parkinson's disease: design and methods of the CALM-PD Study. Parkinson Study Group. Clin Neuropharmacol 2000;23:34-44.

13. Erdoğmuş N. Gazi Üniversitesi Tıp Fakültesi Tıpta Uzmanlık Tezi. 2007.

14. Schapira AH, Barone P, Hauser RA, Mizuno Y, Rascol O, Busse M, Salin L, Juhel N, Poewe W, Pramipexole ERSG. Extended-release pramipexole in advanced Parkinson disease: a randomized controlled trial. Neurology 2011;77:767-774.

15. Poewe W, Rascol O, Barone P, Hauser RA, Mizuno Y, Haaksma M, Salin L, Juhel N, Schapira AH, Pramipexole ERSG. Extended-release pramipexole in early Parkinson disease: a 33-week randomized controlled trial. Neurology 2011;77:759-766.

16. Rascol O, Barone P, Hauser RA, Mizuno Y, Poewe W, Schapira AH, Salin L, Sohr M, Debieuvre C, Pramipexole Switch Study G. Efficacy, safety, and tolerability of overnight switching from immediate- to once daily extended-release pramipexole in early Parkinson's disease. Mov Disord 2010;25:2326-2332.

17. Wang Y, Sun S, Zhu S, Liu C, Liu Y, Di Q, Shang H, Ren Y, Lu C, Gordon MF, Juhel N, Chen S. The efficacy and safety of pramipexole ER versus IR in Chinese patients with Parkinson's disease: a randomized, double-blind, double-dummy, parallel-group study. Transl Neurodegener 2014;3:11. 